\title{
Toleransi Remaja Islam Kepada Pemeluk Agama yang Berbeda: Studi Ekstrakurikuler Rohani Islam (Rohis) SMA di Bekasi, Jawa Barat
}

\author{
Ismi Apriliani \& Hatim Gazali \\ STKIP Kebangkitan Nasional-Sampoerna School of Education \\ (The Sampoerna University) \\ e-mail: ismiapriliani2016@gmail.com
}

\begin{abstract}
Diversity is a blessed but also can be a cause of destructive conflict like already happened at some places in Indonesia. Based on that fact, tolerance is a value that needs to be inculcated to every student, through co curricular and extra-curricular activity like Moslem Youth Community at school. This research aims to describe about tolerance categories Moslem Youth Community member of a school in Bekasi. Method of this research is qualitative and data collected by interview and document analysis. Participants were chosen based on purposive sampling that include its coordinators, teacher who in charge for that extra-curricular, and mentor. This research got result that Moslem Youth Community of that school accept and respect to diversity based on their awareness, and they give others chances to do their worship, although they did not do an action to support it. In conclusion, that Moslem Youth Community is in passive tolerance category.
\end{abstract}

Keywords: Tolerance, Youth, ROHIS, Multicultural Education, Diversity. 


\section{Pendahuluan}

Indonesia merupakan sebuah negara dengan tingkat keanekaragaman yang sangat tinggi. Hal ini dapat dilihat dari beberapa aspek seperti keberagaman suku, etnis, dan agama. Indonesia memiliki setidaknya 300 suku dengan 200 bahasa daerah yang berbeda, 14 etnis (Hanum, 2011), serta 6 agama besar yaitu Islam, Kristen, Katholik, Hindu, Budha, dan Khonghucu (Cholil, Abidin, Rahayu, \& Asyhari, 2009). Keberagaman ini merupakan sebuah kekayaan yang tidak banyak dimiliki oleh bangsa lain. Selain sebagai kekayaan, keberagaman juga memiliki potensi menjadi sumber konflik, seperti yang terjadi di Sampang, Bekasi, Ambon, dan Solo pada beberapa waktu yang lalu. Bentrokan yang terjadi antar kelompok merupakan bentuk dari tindakan-tindakan intoleransi yang merugikan.

Pencegahan kasus-kasus intoleransi dapat dilakukan melalui penanaman nilainilai toleransi kepada masyarakat, yang salah satunya dilakukan melalui pendidikan, karena menurut Chidester, Dexter dan James (2003) pendidikan adalah pusat penanaman toleransi. Pendidikan bertanggung jawab terhadap tingkat kognitif seseorang, yang turut menentukan tingkat toleransi seseorang, sehingga pendidikan berpengaruh pada tingkat toleransi (dalam Chidester, Dexter \& James, 2003). Penanaman toleransi tidak hanya dilakukan melalui kegiatan ko-kurikuler namun juga melalui kegiatan ekstrakurikuler. Hal ini sesuai dengan PERMENDIKNAS RI No. 39 Tahun 2008 pasal Pembinaan Kesiswaan pasal 3, ayat 1 yang menyatakan bahwa "pembinaan kesiswaan dilaksanakan melalui kegiatan ekstrakurikuler dan kokurikuler." Ayat 2 menyatakan bahwa salah satu materi pembinaan kesiswaan adalah demokrasi, hak asasi manusia, pendidikan politik, lingkungan hidup, kepekaan dan toleransi sosial dalam konteks masyarakat plural. Salah satu bentuk ekstrakurikuler yang terdapat pada sebuah Sekolah Menengah Atas (SMA) di daerah Bekasi, Jawa Barat adalah ekstrakurikuler Kerohanian Islam (ROHIS). Sekolah lokasi penelitian merupakan sekolah dengan latar belakang agama siswa yang homogen dan memiliki berbagai perkumpulan siswa seperti Kerohanian Islam, Kerohanian Kristen (ROKRIS), dan lainlain.

Kegiatan ROHIS di SMA tidak hanya diperuntukkan bagi pengurusnya, namun juga bagi siswa-siswi muslim secara umumdi sekolah tersebut. Hal tersebut 
memberikan peluang bagi ROHIS untuk melakukan penanaman nilai-nilai toleransi kepada setiap siswa muslim. Selain itu, sebagian pengurus ROHIS juga aktif di berbagai ekstrakurikuler lain. Hal tersebut memberikan kesempatan kepada pengurus ROHIS untuk memberikan pengaruhnya kepada organisasi ekstrakurikuler lain di sekolah tersebut. Hal ini sesuai dengan Maio dan Haddock (2010) yang menjelaskan bahwa sikap dapat dipengaruhi oleh kelompok dimana kita berada. Demikian pula sebaliknya seorang individu dapat pula mempengaruhi sikap kelompoknya.

Penelitian ini adalah sebuah upaya untuk mengetahui sikap atau cara pandang para pengurus ROHIS terhadap pemeluk agama yang berbeda. Dalam perspektif kognitif disebutkan bahwa pikiran dan penjelasan yang diungkapkan seseorang mempengaruhi tindakannya. Sedangkan perspektif sosio-kultural menyatakan bahwa terdapat kekuatan sosial dan budaya yang dapat mempengaruhi perilaku seseorang, contohnya adalah pengaruh orang lain seperti pengaruh orang tua dan teman (Wade \& Tarvis, 2008). Pengetahuan dari penelitian ini dapat digunakan sebagai bahan pertimbangan dalam usaha pengembangan pembelajaran toleransi melalui ROHIS.

\section{Metode penelitian}

Metode yang digunakan dalam penelitian ini adalah metode penelitian kualitatif, yaitu penyelidikan yang bertujuan menggambarkan kehidupan dari perspektif partisipan. Dari metode penelitian tersebut didapat pemahaman yang lebih baik mengenai realitas sosial yang berfokus pada proses, makna dari pola-pola (Flick, Kardorff \& Steinke (eds.), 2004). Tujuan penelitian ini adalah untuk mengetahui bagaimana sikap toleransi pengurus ekstrakurikuler ROHIS terhadap pemeluk agama lain. Oleh karena itu diperlukan data dan analisis kualitatif sehingga temuan penelitian nantinya dapat memberikan jawaban secara mendalam.

Subjek penelitian ini adalah pengurus ROHIS dan pembinanya, serta alumni yang tergabung dalam forum alumni ROHIS. Pemilihan partisipan dilakukan berdasarkan purposeful random sampling, yaitu prosedur pemilihan partisipan secara acak sebagai informan wawancara. Tujuan prosedur ini adalah untuk mendapatkan informasi yang dan bermanfaat untuk menjawab pertanyaan penelitian ini melalui perspektif pihak-pihak yang terlibat aktif dalam kegiatan ROHIS. Berdasarkan 
pertimbangan tersebut maka peneliti memilih ketua umum, koordinator divisi keputrian (ketua putri), ketua umum forum alumni ROHIS (sekaligus mentor), dan pembina ROHIS sebagai partisipan.

Pengumpulan data pada penelitian ini dilakukan dengan menggunakan wawancara serta dokumen analisis sebagai pendukungnya. Wawancara dilakukan terhadap ke empat partisipan. Jenis wawancara yang akan digunakan adalah elite interview. Pemilihan partisipan didasari pada jabatan partisipan pada organisasi ROHIS, yaitu ketua umum dan kordinator divisi keputrian ROHIS periode 2011-2012. Peran partisipan sebagai pemimpin dalam organisasi diharapkan dapat memberikan data yang mendetail. Wawancara juga dilakukan kepada pembina ROHIS yang berperan dalam pembinaan serta pengawas para pengurus. Nara sumber lainnya adalah alumni yang aktif menjadi mentor dalam kegiatan ROHIS. Alumni yang dipilih sebagai partisipan adalah ketua umum Forum Alumni ROHIS yang aktif menjabat. Peneliti menggunakan catatan mengenai topik-topik yang ditanyakan dalam mewawancarai partisipan, namun penjelasan partisipan di luar topik yang dapat memperkaya data masih dimungkinkan (semi struktur). Instrumen yang digunakan dalam teknik pengumpulan data ini adalah pedoman wawancara.

Data akan diperoleh melalui berbagai dokumen yang terkait dengan subjek penelitian, berupa blog ROHIS, akun-akun jejaring sosial yang dimiliki ROHIS, proposal kegiatan, Laporan Pertanggung Jawaban kegiatan, serta Anggaran Dasar dan Anggaran Rumah Tangga ROHIS. Data-data yang diperoleh dari dokumen-dokumen tersebut akan dikategorikan dan digunakan sebagai sumber tambahan untuk mendukung hasil wawancara dengan partisipan. Instrumen yang digunakan adalah pedoman analisis dokumen yang disesuaikan dengan pedoman wawancara.

Teknik analisis kualitatif yang digunakan dalam penelitian ini terdiri dari 5 tahap. Menurut Yin (2011), tahap pertama adalah pengorganisasian data ke dalam urutan yang logis, dapat berdasarkan kronologi, tema, dan hirarki. Kedua, pengkategorisasian data untuk dikelompokkan ke dalam tema-tema atau kategori tertentu dan pemberian kode. Ketiga, pemeriksaan kembali kategori yang telah dibuat sebelumnya dan melakukan pengubahan/ penambahan/ pengurangan jika dibutuhkan. Keempat, penyusunan data yang telah disusun ke dalam bentuk naratif, sekaligus 
menginterpretasikan data. Kelima adalah penarikan kesimpulan hasil penelitian yang terkait dengan penyusunan data secara naratif pada tahap sebelumnya.

\section{Hasil Penelitian}

\section{Kategori toleransi pengurus ROHIS}

Peneliti menggunakan 4 kategori toleransi yang didasarkan pada beberapa literatur maupun penelitian-penelitian sebelumnya mengenai toleransi. Penelitian Setara Institute pada tahun 2010 menyatakan bahwa terdapat dua jenis intoleransi, yaitu intoleransi aktif dan pasif. intoleransi aktif adalah kondisi dimana seseorang tidak dapat menerima perbedaan dan melakukan tindakan kekerasan untuk menunjukkan ekspresi ketidaksukaan terhadap perbedaan. Sedangkan, intoleransi pasif adalah kondisi dimana seseorang menerima adanya perbedaan karena adanya konsekuensi sosial dan memiliki gagasan yang menganggap bahwa kelompok lain salah, namun tidak termanifestasikan menjadi tindakan.

Dalam penelitian mengenai toleransi beragama mahasiswa (Bahari, 2010) mendefinisikan toleransi sebagai kesadaran individu untuk menghargai, menghormati, memperbolehkan adanya perbedaan keyakinan serta memberikan kesempatan kepada pihak yang berbeda untuk melaksanakan praktik keagamaan, sekalipun bertentangan, dengan tujuan menciptakan kehidupan bersama yang lebih baik. Menurut Walzer dalam Misrawi (2010) terdapat lima hakikat toleransi yaitu menerima perbedaan dengan tujuan untuk kehidupan yang damai; membiarkan kelompok yang berbeda untuk tetap ada di dunia; walaupun kurang bersimpati, namun tetap menerima bahwa orang lain juga memiliki hak; menyatakan keterbukaan terhadap orang lain, dengan menghargai, mau mendengarkan dan belajar dari orang lain; menitikberatkan aspek otonomi dan secara antusias mendukung perbedaan. Dengan demikian, definisi toleransi dalam penelitian ini adalah menerima dan menghormati perbedaan dan menunjukkannya dengan memberikan kesempatan kepada pemeluk agama yang berbeda untuk melaksanakan praktik keagamaan dan mendukungnya secara antusias.

Berdasarkan konsep-konsep mengenai toleransi yang telas dipaparkan di atas, maka toleransi yang dimaksud dalam penelitian ini dibagi menjadi dua, yaitu toleransi pasif dan toleransi aktif. Toleransi pasif adalah kemampuan untuk menerima dan 
menghormati perbedaan pendapat, pandangan, perilaku, dan kebiasaan serta memberikan kesempatan tanpa melakukan suatu tindakan nyata yang bertujuan untuk mendukung pelaksanaan praktik peribadatan agama lain, namun tetap berusaha untuk menciptakan hubungan sosial yang baik dan hidup bersama dengan damai dengan kesadaran pribadi. Definisi dari toleransi aktif adalah kemampuan untuk menerima dan menghormati perbedaan pendapat, pandangan, perilaku, kebiasaan dan memberikan kesempatan serta mendukung kelompok agama yang berbeda untuk menjalani praktik keagamaan dengan suatu tindakan nyata yang berbeda yg bertujuan menciptakan hubungan sosial yang baik dan hidup bersama dengan damai dengan kesadaran sendiri.

Berdasarkan definisi di atas maka indikator dari setiap kategori adalah seperti pada tabel di bawah ini:

Tabel 1. Kategori toleransi

\begin{tabular}{|c|c|c|c|}
\hline Toleransi Aktif & Toleransi Pasif & Intoleransi Pasif & Intoleransi Aktif \\
\hline $\begin{array}{l}\text { Menerima dan } \\
\text { menghormati } \\
\text { perbedaan }\end{array}$ & $\begin{array}{l}\text { Menerima dan } \\
\text { menghormati } \\
\text { perbedaan }\end{array}$ & $\begin{array}{l}\text { Menerima } \\
\text { perbedaan }\end{array}$ & $\begin{array}{l}\text { Tidak menerima } \\
\text { perbedaan }\end{array}$ \\
\hline $\begin{array}{l}\text { Berdasarkan } \\
\text { kesadaran sendiri. }\end{array}$ & $\begin{array}{l}\text { Berdasarkan } \\
\text { kesadaran sendiri }\end{array}$ & $\begin{array}{l}\text { Berdasarkan } \\
\text { konsekuensi } \\
\text { hubungan sosial }\end{array}$ & \\
\hline $\begin{array}{l}\text { Memberikan } \\
\text { dukungan kepada } \\
\text { pemeluk agama lain } \\
\text { untuk beribadah } \\
\text { dengan suatu } \\
\text { tindakan nyata. }\end{array}$ & $\begin{array}{l}\text { Memberikan } \\
\text { kesempatan } \\
\text { pemeluk agama lain } \\
\text { untuk beribadah } \\
\text { namun tidak } \\
\text { melakukan suatu } \\
\text { tindakan nyata }\end{array}$ & $\begin{array}{l}\text { Terdapat gagasan } \\
\text { yang menganggap } \\
\text { bahwa kelompok } \\
\text { lain salah, namun } \\
\text { tidak } \\
\text { termanifestasikan } \\
\text { menjadi tindakan. }\end{array}$ & $\begin{array}{l}\text { Melakukan } \\
\text { tindakan kekerasan } \\
\text { untuk menunjukkan } \\
\text { ekspresi } \\
\text { ketidaksukaan } \\
\text { terhadap perbedaan. }\end{array}$ \\
\hline
\end{tabular}

Peneliti menggunakan indikator-indikator tersebut sebagai acuan dalam menganalisis data yang didapatkan.

Dalam wawancara, ketua ROHIS menyatakan bahwa di Indonesia terdapat berbagai agama tidak hanya Islam. Oleh karena itu, kita juga harus menghormati pemeluk agama lainnya. Menurutnya, para pengurus ROHIS sudah dididik melalui kegiatan, diskusi maupun nasihat-nasihat dari pembina dan mentor untuk berperilaku baik terhadap sesama muslim, dan ia merasa harus bersikap baik pula kepada pemeluk agama yang berbeda. 
Ketua umum ROHIS juga menyatakan bahwa pernah ada kegiatan bersama antara pengurus ROHIS dengan para anggota ROKRIS dalam bentuk pertandingan futsal. Salah seorang pengurus ROHIS menginisiasi kegiatan pertandingan antara ROHIS dan ROKRIS. Tujuan kegiatan tersebut menurutnya hanya untuk melakukan hobi bersama-sama tanpa memikirkan perbedaan agama antara dua kelompok tersebut.

Koordinator divisi keputrian menyatakan pendapat yang bersesuaian dengan ketua ROHIS. Menurut partisipan kedua, dalam al-Qur'an dijelaskan bahwa muslim harus menerima dan menghargai agama orang lain. Oleh karena itu, tidak perlu ada perselisihan antar agama. Ia mengungkapkan bahwa berteman dengan pemeluk agama yang berbeda merupakan hal yang mengasyikkan karena bisa saling bertukar cerita tentang keunikan masing-masing, tanpa melupakan prinsip masing-masing.

Pernyataan-pernyatan ketua umum dan ketua putri ROHIS menunjukkan bahwa keduanya menerima dan menghormati perbedaan. Toleransi adalah sikap menghargai adanya perbedaan dengan orang lain (Winarta, 2009). Ujan dkk. (2009, h. 97) menyatakan bahwa dalam menghadapi perbedaan seseorang tidak perlu melebur dan kehilangan identitas, namun perlu hidup bersama dengan identitas masing-masing dan tidak membuat perbedaan yang ada menjadi sumber konflik.

Penerimaan perbedaan dapat dilakukan karena adanya motivasi tertentu dan motivasi tersebutlah yang membedakan intoleransi pasif dengan toleransi baik pasif maupun aktif (Hasani dkk., 2010). Intoleransi pasif adalah menerima perbedaan karena konsekuensi hubungan sosial, yang merupakan motivasi eksternal. Motivasi eksternal adalah keinginan karena adanya hukuman atau penghargaan dari pihak luar (Lepper, Dialdin, \& Drake, 2005). Sedangkan motivasi intrinsik adalah motivasi yang mendasari toleransi, karena sikap penerimaan perbedaan yang dilakukan berasal dari diri sendiri.

Pernyataan-pernyataan partisipan di atas menggambarkan pilihan-pilihan sikap mereka terhadap eksistensi perbedaan. Kemampuan partisipan untuk menentukan pilihan dapat merupakan sebuah indikator bahwa partisipan memiliki motivasi intrinsik, yaitu motivasi untuk mengontrol atau menentukan pilihan. Salah satu bentuk motivasi intrinsik adalah keinginan untuk mengontrol atau menentukan pilihan (Lepper, Sethi, Dialdin, \& Drake, 2005). Motivasi ini ditandai dengan membuat pilihan, mengontrol sendiri hasil dari pilihan tersebut dan menentukan nasib sendiri. Dalam pernyataannya

At.t Volume. 1, No. 1, Januari - Juni 2016 
partisipan memilih untuk berbuat baik dan bergaul bersama teman yang berbeda agama. Di lain sisi mereka memiliki kesempatan untuk memilih sikap lainnya.

Perbedaan basis agama antara ROHIS dan ROKRIS tidak dikhawatirkan oleh ketua ROHIS. Ia menyetujui pendirian ROKRIS ataupun ekstrakurikuler berbasis agama lain, karena sebagai sekolah miliki pemerintah setiap orang memiliki hak yang sama. Ketua putri ROHIS maupun ketua forum alumni pun memiliki pendapat serupa. Pendapat kedua partisipan terhadap pembentukan ROKRIS sebagai ekstrakurikuler di sekolah tersebut mengindikasikan bahwa mereka tidak menghalanginya. Sikap yang partisipan tunjukkan sesuai dengan kebijakan pemerintah (Menteri Agama) mengenai prinsip dasar kerukunan yaitu "tidak saling mengganggu antara kelompok-kelompok agama yang berbeda" (Muhaimin dalam Reslawati, 2007, h. 14). Tidak menghalangi pendirian ekstrakurikuler ROKRIS yang dilakukan oleh kedua partisipan terkait dengan konsep bahwa pada masyarakat yang menganut multikulturalisme setiap kelompok memiliki kesempatan yang sama untuk berekspresi, hidup berdampingan dan bekerjasama dengan orang lain.

Dalam pernyataannya ketum ROHIS dan ketua putri mengindikasikan adanya motivasi eksternal yang mendorong mereka untuk memberikan kesempatan kepada ROKRIS untuk menjadi organisasi resmi. Motivasi eksternal tersebut adalah kondisi sekolah yang merupakan milik pemerintah. Pengertian dari motivasi eksternal adalah keinginan untuk melakukan sesuatu untuk memperoleh penghargaan dari pihak luar atau menghindari hukuman eksternal (Santrock, 2003). Dalam hal ini, hal eksternal yang menjadi motivasi adalah fakta mengenai adanya perbedaan dan adanya aturan dari pemerintah yang memberikan kesempatan atau hak yang sama bagi setiap warga negara untuk menjalankan agama.

Bentuk lain dari toleransi yang dikembangkan di sekolah lokasi penelitian adalah pelaksanaan khutbah Jum'at dan kegiatan keputrian ROHIS dilakukan dalam waktu bersamaan dengan kegiatan kebaktian oleh para siswa dan guru beragama nasrani atau yang disebut kerohanian Kristen (ROKRIS). Dalam kebaktian ROKRIS terdapat pelantunan lagu puji-pujian, disaat yang bersamaan sedang berlangsung khutbah Jum'at ataupun pemberian materi pada kegiatan keputrian. Pelaksanaan kegiatan tersebut tidak pernah menjadi masalah bagi pengurus ROHIS maupun ROKRIS. Menurut pembina 
ROHIS karena ROHIS dan ROKRIS ada di bawah naungan sekolah yang merupakan organisasi pemerintah maka diharapkan tidak ada perselisihan di antara keduanya. Akan lebih baik jika kedua organisasi tersebut dapat saling mendukung.

Pembina ROHIS mengungkapkan bahwa baik ROHIS maupun ROKRIS tidak pernah menentang atau mengganggu kegiatan satu sama lain. Keduanya menunjukkan sikap bahwa setiap kelompok memiliki hak untuk menjalankan aktifitasnya. Hal ini sesuai dengan teori negosiasi prinsip yang menyatakan bahwa konflik disebabkan oleh ketidakselarasan dan perbedaan pandangan (Ujan dkk., 2009). Konflik dapat diselesaikan dengan negosiasi untuk kepentingan bersama hingga setiap pihak memiliki kebebasan dan setara.

Dalam wawancara peneliti menanyakan pendapat partisipan mengenai tindakan intoleransi yang dilakukan oleh berbagai kelompok. Ketua ROHIS menyatakan bahwa ia tidak menyetujui digunakannya kekerasana untuk menyelesaikan masalah karena hal tersebut dapat merusak citra Islam. Menurutnya, penyelesaian permasalahan dapat dilakukan melalui dialog atau komunikasi. Ketua putri menyatakan hal yang sama. Menurutnya, musyarawarah seharusnya dilakukan sebelum dilakukannya kekerasan, karena kekerasan merupakan hal yang salah. Pendapat partisipan sesuai dengan teori hubungan masyarakat yang diungkapkan oleh Fisher dalam Ujan dkk., (2009), konflik disebabkan oleh ketidakpercayaan dan permusuhan antara kelompok yang berbeda sehingga tercipta kelompok-kelompok yang berlawanan. Penyelesaian konflik menurut teori tersebut adalah dengan meningkatkan komunikasi dan toleransi, untuk menciptakan rasa saling pengertian. Penggunaan komunikasi merupakan sebuah bentuk pendekatan dalam mengelola konflik, yaitu pendekatan penyelesaian.

Terkait dengan tindakan kekerasan yang dilakukan oleh beberapa kelompok muslim, peneliti menanyakan pendapat para partisipan mengenai ROHIS teroris. Terorisme adalah "penggunaan kekerasan secara luas dan massif untuk mencapai tujuan“" (Hasani dkk., 2011, h. 20). Berdasarkan definisi tersebut maka terorisme merupakan bentuk tindakan intoleransi. Menurut pembina selalu dilakukan pemantauan terhadap setiap kegiatan ROHIS, sehingga setiap siswa terhindar dari penjerumusan kepada terorisme. Pemantauan dilakukan dengan cara bekerja sama dengan para alumni ROHIS yang telah dipercaya membina para pengurus ROHIS. kepercayaan diberikan 
kepada alumni karena mereka merupakan kader-kader dari ROHIS. Adapun pelibatan pihak luar hanya dilakukan berdasarkan rekomendasi alumni yang dapat dipercaya. Ketua ROHIS pun menyatakan bahwa setiap kegiatan mereka harus mendapat persetujuan dari pembina. Pengurus ROHIS melaporkan kepada pembina setiap mereka berhubungan dengan pihak luar sekolah. Laporan diberikan melalui rapat koordinasi maupun pertemuan informal. Pembina pun selalu mengingatkan kepada para pengurus untuk melapor jika ada pihak-pihak yang mencurigakan seperti pihak yang mengatakan adanya nabi baru dan memperbolehkan melawan orang tua.

Ketua umum ROHIS menyatakan bahwa ROHIS anti terorisme. Menurut ketua umum, ketua putri dan ketua forum alumni, tanggapan yang perlu diberikan untuk menjawab isu ROHIS teroris adalah dengan menunjukkan perilaku yang baik, membuktikan bahwa pengurus ROHIS merupakan siswa-siswa yang dapat berprestasi, berpikiran kritis, jujur dan peduli, dan tidak memasukkan agenda terkait terorisme dalam program ROHIS. Menurut partisipan, terorisme tidak akan membawa manfaat.

Pemilihan sikap mengenai isu ROHIS teroris oleh para partisipan dianalisis menggunakan theory of reasoned action. Maio \& Haddock (2010) menjelaskan bahwa dalam theory of reasoned action terdapat dua komponen dasar yang menyebabkan seseorang berperilaku. Komponen pertama adalah sikap terhadap perilaku tersebut. Maksudnya adalah pemikiran seseorang apakah perilaku tersebut berdampak baik atau buruk. Komponen ini terkait dengan ekspektasi terhadap hasil dari perilaku nantinya. Komponen kedua adalah norma subjektif. Arti dari komponen ini adalah pandangan orang lain terhadap perilaku yang akan dilakukan. Kedua komponen tersebut akan membentuk kecenderungan untuk berperilaku yang kemudian menjadi perilaku atau tindakan individu.

Dalam konteks pernyataan partisipan, mereka menilai bahwa sikap yang baik kepada orang lain, jujur, peduli, dan lain-lain akan menghasilkan hal yang baik, sehingga mereka merasa perlu melakukannya. Ditambah dengan pertimbangan bahwa orang di luar ROHIS akan melihat hal tersebut sebagai bukti yang positif bahwa ROHIS bukanlah sarang teroris, maka semakin kuat kecenderungan untuk berperilaku demikian.

Data dan analisis yang telah dilakukan menunjukkan bahwa pengurus ROHIS memiliki kategori toleransi pasif. Indikator yang terpenuhi adalah: a) Pengurus ROHIS 
menerima dan menghormati adanya perbedaan yang ditunjukkan dengan berbagai sikap yang baik kepada pemeluk agama lain. Motivasi dari sikap tersebut berasal dari dalam diri, yaitu kesadaran untuk menghindari konflik dengan kelompok yang berbeda. Selain itu, pengurus ROHIS juga memiliki motivasi dari luar, yaitu kondisi sekolah yang merupakan sekolah negeri (milik pemerintah) menjadikan setiap orang mempunyai hak yang sama dalam melaksanakan kegiatan keagamaan. Pengurus ROHIS juga menyadari bahwa Indonesia memiliki tingkat keberagaman yang tinggi. b) Para pengurus ROHIS memberikan kesempatan kepada pemeluk agama lain untuk menjalani kegiatan keagamaan. Namun, tidak melakukan suatu tindakan nyata yang mendukung kegiatan keagamaan kelompok lain.

\section{Diskusi}

Pembahasan yang peneliti jabarkan dalam bagian diskusi adalah latar belakang atau alasan yang mendasari pengurus ROHIS dalam bertindak toleran terhadap pemeluk agama yang berbeda. Lacewing (2008) berpendapat bahwa kita perlu mampu membedakan toleransi sebagai tindakan dengan toleransi sebagai kebajikan, karena tidak semua tindakan toleran merupakan sikap toleransi. Hal ini terkait dengan pernyataan Almagor (1994) bahwa tindakan toleransi atas dasar kepentingan diri sendiri dapat menjadi dasar tindakan intoleransi di masa mendatang.

Pembahasan selanjutnya adalah mengenai cara-cara pembelajaran toleransi yang terjadi di ROHIS. Dalam penelitian ini, peneliti menjelaskan cara-cara pembelajaran toleransi yang dialami oleh para pengurus di dalam ekstrakurikuler ROHIS, untuk mengetahui bagaimana pengaruh ROHIS dalam pembentukan sikap pengurusnya terhadap pemeluk agama lain. Menurut Pastorino dan Portillo (2012) berbagai cara pembelajaran mempengaruhi sikap seseorang. Sikap atau cara pandang individu ikut membentuk perilakunya (Wade \& Travis, 2009). Terdapat berbagai teori mengenai bagaimana seorang manusia belajar, di antaranya adalah melalui diskusi dengan orang lain (teori Vygotsky) dan juga pembelajaran dengan cara mengobservasi perilaku orang lain dan menirukannya (teori sosial kognitif). Cara-cara pembelajaran itu melibatkan lingkungan dalam mempengaruhi sikap atau cara pandang seseorang. Peneliti juga

At.t Volume. 1, No. 1, Januari - Juni 2016 
menggali sistem lingkungan di ekstrakurikuler ROHIS, yang dapat mempengaruhi para pengurusnya berdasarkan teori kontekstual ekologis.

\section{Latar belakang toleransi pengurus ROHIS}

Lacewing (2008) menyatakan bahwa terdapat dua jenis toleransi, yang dibedakan berdasarkan latar belakang seseorang dalam melakukan tindakan toleransi. Jenis toleransi yang pertama adalah toleransi sebagai perilaku. Dalam jenis seseorang dapat berlaku toleran walaupun sebenarnya ia bukanlah orang yang toleran. Hal ini sama dengan seseorang yang memberikan amal dengan niat untuk memberikan kesan yang baik tentang dirinya di hadapan orang lain. Jenis toleransi yang kedua adalah toleransi sebagai kebajikan. Alasan adanya toleransi ini adalah karena tindakan toleransi dilakukan untuk menghargai orang lain (secara moral) ataupun sebuah komitmen untuk menjaga kehidupan yang damai bersama orang lain (secara politis).

Dua jenis toleransi yang dijelaskan oleh Lacewing (2008) di atas, menjadi dasar untuk analisis yang dilakukan oleh peneliti guna meninjau toleransi yang dimiliki oleh para partisipan. Pernyataan Lacewing (2008) sejalan dengan yang diungkapkan oleh Almagor (1994), seseorang dikatakan bertoleransi jika alasannya bertindak adalah menghargai orang lain dan meyakini bahwa orang lain memiliki hak untuk menganut keyakinannya, dan melaksanakan kebebasannya untuk memilih, sejauh ia tidak melukai orang lain. Seseorang tidak dapat dikatakan bertoleransi jika melakukan tindakan toleran namun didasari oleh kepentingan pribadi. Tindakan toleran tersebut dilakukan karena dapat mendatangkan keuntungan pribadi baginya.

Dalam wawancara partisipan menyatakan alasan-alasan untuk bertindak toleran. Ketua umum ROHIS menyatakan bahwa karena keberagaman yang ada di Indonesia maka kita harus menghormati pemeluk agama lain dengan bersikap baik dan memberikan kesempatan kepada orang lain untuk menjalankan hak melaksanakan agamanya. Ketua putri pun berpendapat bahwa terdapat penjelasan untuk menghargai agama orang lain di dalam al-Qur'an, sehingga tidak perlu ada perselisihan antar agama. Ditambah dengan pernyataan ketua forum alumni bahwa pendirian ROKRIS perlu dilakukan agar ROKRIS memiliki payung hukum dan mendapat kesempatan yang sama untuk beribadah. 
Pendapat-pendapat yang dinyatakan oleh para partisipan menunjukkan bahwa pengurus ROHIS dapat menghormati hak yang dimiliki oleh kelompok agama lain. Para partisipan tidak mengungkapkan adanya tendensi bahwa tindakan toleran yang dilakukannya memberikan suatu keuntungan tertentu bagi dirinya maupun ROHIS. Alasan partisipan bertindak toleran sejalan dengan yang disampaikan oleh Lacewing (2008) bahwa toleransi sebagai kebajikan dilandasi oleh rasa menghargai hak orang lain atau dilakukan dengan menjaga kedamaian dalam hidup bersama.

Dalam wawancara yang peneliti lakukan, ketua umum ROHIS juga menyatakan pendapatnya bahwa ia tidak menyetujui kekerasan karena hal tersebut dapat memberikan citra negatif terhadap Islam. Pendapat tersebut menunjukkan bahwa selain karena penghargaan terhadap orang lain seperti dijelaskan di atas, ia juga memikirkan kepentingan kelompoknya.Adanya kepentingan kelompok yang tersirat pada pernyataan partisipan pertama, menyebabkan tindakan yang ia lakukan tidak dapat dikatakan sebagai toleransi sebagai kebajikan. Hal ini sesuai dengan dengan Almagor (1994) yang mengungkapkan bahwa toleransi harus berdasar pada kepentingan orang lain, bukan kepentingan diri sendiri. Tindakan toleran semacam ini dapat menjadi bibit intoleransi di masa depan.

ROHIS adalah ujung tombak dari kegiatan-kegiatan keagamaan di sekolah (Salim dkk., 2011). Menurut Koesmarwanti \& Widiyantoro (2002), ROHIS adalah wadah strategis untuk berdakwah. Berdasarkan penelitian yang dilakukan oleh CRCS pada tahun 2011 pada tiga SMA di Jogjakarta, keberadaan ROHIS di sekolah dapat diinisiasi (resepsi, negosiasi, dan resistensi) dengan cara yang beragam oleh para siswa karena sekolah adalah ruang publik, maksudnya sekolah adalah tempat pertemuan beragam individu dan kelompok yang berbeda (Salim dkk., 2011).

Dibutuhkan sikap yang bijak dari para aktifis ROHIS dalam melaksanakan dakwah di sekolah karena perbedaan dapat menstimulasi adanya pertentangan antar siswa, kelompok siswa lainnya akan menjadi oposan yang tidak segan-segan melakukan boikot, secara individual ataupun kelompok, bila salah satu pihak dari gerakan tersebut cukup dominan di organisasi kegiatan siswa. Pertentangan yang dihasilkan dari sikapsikap emosional dapat merugikan pihak ROHIS sendiri, karena sebagai garis depan dakwah di sekolah justru dapat menimbulkan keresahan (Koesmarwanti \& Widiyantoro, 
2002). Pencegahan sikap emosional yang intoleran tersebut dapat dilakukan dengan memberikan pemahaman-pemahaman yang dibutuhkan oleh para aktifis. Menurut Koesmarwanti \& Widiyantoro (2002), salah satu pemahaman yang perlu dimiliki oleh para aktifis ROHIS adalah pemahaman tentang keberagaman.

\section{Cara penanaman nilai-nilai toleransi di ROHIS}

Dalam wawancara partisipan menyatakan bahwa tidak ada kegiatan yang diselenggarakan khusus untuk memberikan pengetahuan dan menanamkan nilai toleransi. Hal ini, tidak berarti di ROHIS tidak terdapat penanaman nilai toleransi. Penanaman toleransi di ROHIS dilakukan melalui beberapa cara. Pembina ROHIS menyatakan bahwa salah satu cara penyampaian mengenai toleransi adalah melalui dialog antara pembina dengan para pengurus. Dialog tersebut terjadi ketika ada forum rapat koordinasi antara pengurus dengan pembina, briefing maupun rapat koordinasi dengan kepala sekolah atau wakil kepala sekolah.

Hal yang disampaikan adalah perlunya menghargai pemeluk agam lain seperti yang terdapat pada al-Qur'an. Implementasinya adalah ROHIS meyakini bahwa mereka dapat bekerjasama dengan kelompok agama lain dalam bidang-bidang sosial yang tidak menyinggung perihal keyakinan terhadap Allah SWT. Pembina juga mengingatkan pengurus ROHIS untuk melaporkan jika ada pihak yang mengajak mereka untuk menentang orang tua, ataupun penjerumusan kepada terorisme. Pengurus ROHIS diajarkan untuk tidak mengikuti ajakan-ajakan semacam itu.

Penyampaian-penyampaian nilai-nilai toleransi dari pembina dapat berpengaruh pada sikap yang terbentuk dalam diri para pengurus. Hal ini terkait dengan penjelasan Maio \& Haddock (2010) bahwa beberapa jenis hubungan antar manusia dapat memberikan efek kepada sikap yang dibentuk dan dipelihara oleh individu. Salah satu jenisnya adalah hubungan antara dua orang yang salah satunya memiliki kekuasaan lebih dibanding yang lain. Pesan atau informasi yang disampaikan oleh seseorang yang lebih berkuasa (powerful people) akan lebih meyakinkan daripada pesan yang disampaikan oleh orang-orang yang kurang berkuasa (powerless). Dalam penelitian ini, pembina memiliki kekuasaan yang lebih tinggi dibandingkan dengan pengurus. Setiap kegiatan yang akan dilakukan oleh pengurus harus dengan sepengetahuan dan izin dari 
pembina. Dengan kondisi hubungan tersebut maka pembina sebagai powerful people bagi para pengurus dapat memberikan pengaruh terhadap perilaku mereka melalui ajakan-ajakannya.

Serupa dengan penuturan pembina, ketua forum alumni ROHIS menyatakan bahwa penanaman nilai-nilai toleransi kepada para pengurus ROHIS disampaikan melalui diskusi informal antara alumni dan pengurus. Diskusi-diskusi informal antara alumni dengan pengurus merupakan salah satu cara pembelajaran. Sesuai dengan teori Vygotsky, diskusi dan interaksi dengan orang lain yang lebih terampil merupakan hal yang penting dalam pembelajaran (Santrock, 2003). Berdasarkan keterangan dari pembina, alumni yang terlibat dalam kegiatan ROHIS adalah mereka yang diketahui memiliki kemampuan yang baik untuk mengkader adik-adiknya. Dengan demikian para alumni yang terlibat merupakan orang-orang yang terampil dibandingkan para pengurus.

Menurut ketua forum alumni ROHIS penyampaian mengenai toleransi hanyalah pengayaan yang disisipkan melalui kegiatan mentoring. Tujuannya untuk memperluas pengetahuan para pengurus. Tidak terdapat alokasi waktu khusus untuk membahas mengenai toleransi secara spesifik, termasuk dalam kegiatan mentoring yang dilaksanakan oleh ROHIS yang sebagian besar mentornya adalah anggota forum alumni ROHIS. Alasan tidak dimasukkannya toleransi sebagai materi dalam mentoring adalah keterbatasan waktu dan pertimbangan bahwa penghargaan terhadap agama lain jarang terdengar di sekolah tersebut. Oleh karena itu, materi toleransi dirasa tidak perlu diberikan secara khusus kepada para pengurus ROHIS

Mentoring oleh Aoki dkk. (2000) dalam Chin, Chien dan Shahizan (2006) didefinisikan sebagai "model pendidikan dan latihan yang mencakup berbagai disiplin." Chin, Chien dan Shahizan (2006) mendefinisikan mentoring sebagai proses yang menggunakan berbagai aspek termasuk kemampuan dari orang yang berpengalaman untuk melakukan bimbingan, didikan dan latihan kepada remaja sesuai tujuan pembelajaran. Menurut Blinn dan Pike (2010) mentoring dapat memberikan manfaat terhadap perkembangan sikap dan sisi afektif peserta didik Mentoring di ROHIS dilaksanakan dengan cara pembentukan kelompok-kelompok yang terdiri dari 5-10 orang pengurus ROHIS.

At.t Volume. 1, No. 1, Januari - Juni 2016 
Mentoring dan proses menirukan suatu perilaku dijelaskan dalam teori kognitif sosial (teori Bandura) yang menekankan konteks sosial (Stromei, 2001). Dalam teori tersebut dijelaskan bahwa individu belajar dengan mengobservasi seseorang yang kemudian mengimitasi perilakunya (disebut sebagai pembelajaran observasional). Dalam pembelajaran observasional, observer dapat memperoleh pengetahuan dan polapola baru perilaku dengan cara mengamati orang lain (modeling). Modeling adalah kekuatan utama dari mentoring. Mentor berkewajiban untuk membuat dirinya menjadi teladan bagi para anak didiknya. Para mentor juga harus mengerti bahwa keteladanan mereka dapat menstimulasi cara pandang anak didiknya.

Dalam wawancara, ketua umum dan ketua putri ROHIS menyatakan bahwa fokus para pengurus ROHIS adalah pelaksanaan program kerja yang telah dirancang. Pembelajaran mengenai sikap kepada pemeluk agama lain tidak dibahas secara khusus di ROHIS. Menurut partisipan, ROHIS belum perlu melaksanakan kegiatan atau program kerja khusus untuk menanamkan nilai-nilai toleransi kepada para pengurusnya. hal ini disebabkan tidak adanya permasalahan antara pengurus ROHIS dengan pemeluk agama lain terkait masalah kepercayaan yang berbeda. Para siswa dapat membaur dan berteman baik dan saling menghargai perbedaan agama yang dianut. Partisipan juga berpendapat bahwa sikap toleransi bergantung pada individu masing-masing.

Penanaman toleransi tidak menjadi pokok program kerja, namun ROHIS berpotensi untuk menjadi sarana pembelajaran mengenai toleransi baik kepada para pengurus maupun anggota (siswa) secara umum. Pembelajaran bagi para pengurus didapat dari pembina dan alumni seperti yang telah dijelaskan. Pembelajaran bagi siswa selain pengurus berpotensi didapat dengan dua cara. Pertama, melalui pengurus ROHIS yang juga memiliki jabatan di ekstrakurikuler lain. Kedua, melalui kegiatan-kegiatan ROHIS yang melibatkan siswa secara umum.

Banyak pengurus ROHIS yang juga memiliki jabatan di ekstrakurikuler lain maupun OSIS. Hal ini membuat adanya kesempatan untuk menyampaikan pengetahuan yang mereka dapatkan dari ROHIS kepada anggota ekstrakurikuler lain. Akses yang dimiliki ROHIS dapat digunakan untuk mempengaruhi kelompok-kelompok lain dengan menyebarkan kultur yang dimiliki ROHIS kepada kelompok siswa lainnya. Akses yang dimiliki ROHIS potensial untuk menyebarkan pembelajaran toleransi yang 
didapatkan oleh pengurus ROHIS kepada pengurus ekstrakuriler lain dan OSIS. Penanaman toleransi yang diserap oleh para pengurus kemungkinan dapat disebarkan lagi ke ekstrakurikuler-ekstrakurikuler lainnya. Maio \& Haddock (2010) menjelaskan bahwa sikap kita dapat dipengaruhi oleh kelompok dimana kita berada. Demikian pula sebaliknya seorang individu dapat pula mempengaruhi sikap kelompoknya.

Kesempatan penyebaran pengaruh ROHIS lainnya adalah melalui kegiatankegiatan yang dijalankan. Terdapat kegiatan ROHIS yang juga melibatkan siswa dari kelompok lain.Contoh kegiatan yang dilakukan pengurus ROHIS adalah tanding futsal antara pengurus ROHIS dengan ROKRIS. Kegiatan tersebut dapat dimanfaatkan untuk menanamkan toleransi, walaupun menurut partisipan tujuan tanding futsal hanyalah untuk menyalurkan hobi bersama-sama. Kegiatan sederhana seperti pertandingan futsal merupakan bentuk interaksi antara dua kelompok yang berbeda. Menurut Unceta dan Medrano (ed., 2010) toleransi dibutuhkan untuk menjalin interaksi sosial, dalam arti bahwa masing-masing pihak yang berinteraksi butuh menerima perbedaan satu sama lain. Interaksi sosial membutuhkan kesepahaman bersama tidak hanya untuk menerima perbedaan satu sama lain, tapi juga untuk mencari persamaan yang dimiliki setiap pihak.

Tidak hanya ROHIS secara organisasi yang berpotensi menjadi tempat penyebaran nilai-nilai toleransi. Demikian pula para pengurusnya secara individu. Contohnya, dari wawancara diketahui bahwa perilaku ketua ROHIS mendapatkan perhatian dari para siswa lainnya. Sebagai ketua, ia diharapkan dapat menjadi panutan bagi teman-temannya. Zenger, Folkman, dan Edinger (2012) mengungkapkan bahwa perhatian setiap orang tertuju pada tindakan atau sikap yang dilakukan oleh seorang pemimpin. Perilaku pemimpin mengarahkan anggotanya untuk melakukan hal yang serupa. Pemberian keteladanan adalah cara yang dapat dilakukan untuk menjadi panutan bagi yang lain. Peran keteladanan yang partisipan miliki merupakan suatu kesempatan untuk dapat memberikan contoh kepada siswa lainnya, termasuk mengenai toleransi.

Data-data yang didapatkan peneliti menggambarkan bahwa proses pembelajaran mengenai toleransi di ROHIS tidak teragendakan namun tetap berjalan. Proses pembelajaran tersebut terjadi melalui komunikasi, interaksi antara pembina dengan pengurus, alumni atau mentor dengan pengurus. Terdapat juga potensi-potensi terjadinya proses pembelajaran antara pemimpin ekstrakurikuler ROHIS kepada para

At.t Volume. 1, No. 1, Januari - Juni 2016 
anggotanya (pengurus ROHIS secara umum). Selain itu, kebijakan kepala sekolah beserta wakil-wakilnya dapat pula mempengaruhi proses pembelajaran yang terjadi di ROHIS.

Dalam penelitian ini, peran setiap komponen ekstrakurikuler ROHIS dikaitkan dengan teori kontekstual ekologis dari Brofenbrenner. Teori ini menekankan pentingnya pengaruh lingkungan terhadap perkembangan remaja. Brofenbrenner dalam Shaffer \& Kipp (2010) mendefinisikan lingkungan sebagai sebuah tempat terstruktur (sistem), dimana setiap sistem merupakan bagian dari sistem berikutnya. Dengan kata lain, seorang manusia berada di beberapa sistem lingkungan sekaligus. Mulai dari lingkungan terdekat seperti keluarga sampai dengan konteks yang lebih luas seperti budaya. Masing-masing sistem lingkungan mempengaruhi sistem yang lain dan individu yang berada di dalamnya.

Dalam teori kontekstual ekologis, terdapat lima sistem lingkungan yang terdiri dari mikrosistem, mesosistem, eksosistem, makrosistem, dan kronosistem (Brofenbrenner dalam Santrock, 2007). Mikrosistem merupakan aktivitas dan interaksi terdekat di sekitar manusia (remaja). Sistem ini dapat meliputi keluarga, kawan sebaya, sekolah, guru, dan lingkungan sekitar. Dalam sistem ini, tidak hanya lingkungan yang mempengaruhi remaja, namun remaja dapat pula mempengaruhi lingkungannya. Dalam konteks ROHIS, hubungan antara pengurus dengan pembina, alumni serta sesama pengurus merupakan mikrosistem dari seorang pengurus aktif ROHIS.

Sistem lingkungan selanjutnya adalah mesosistem. Mesosistem adalah hubungan antara dua atau lebih mikrosistem. Contohnya, hubungan antara pengalaman sekolah dengan pengalaman keluarga, dimana pola asuh orang tua mempengaruhi sikap anak terhadap gurunya.

Eksositem merupakan sistem lingkungan yang ketiga. Eksosistem merupakan "suatu situasi sosial dimana remaja tidak memiliki peran aktif namun mempengaruhi pengalaman remaja" (Santrock, 2007, h. 58). Dalam konteks ROHIS contohnya adalah kebijakan-kebijakan sekolah yang harus dipatuhi oleh para pengurus ROHIS dalam menjalankan kegiatan ekstrakurikulernya.

Makrosistem adalah "budaya dimana remaja hidup" (Santrock, 2007, h. 58). Makrosistem merupakan nilai-nilai yang berlaku pada mikrosistem, mesosistem, dan 
eksosistem dari remaja yang disampaikan dari generasi ke generasi. Contohnya adalah prinsip dari toleransi yang dipegang oleh ROHIS mulai dari alumni hingga pengurus aktif ROHIS dan juga pembina.

Kronosistem adalah sistem lingkungan yang terakhir. Kronosistem adalah "pola dari peristiwa-peristiwa lingkungan, transisi dari rangkaian kehidupan dan keadaankeadaan sosio historis" (Santrock, 2007, h. 58). Dalam konteks penelitian ini, pusat dari sistem lingkungannya adalah pengurus ROHIS periode 2011/2012. Berdasarkan data yang diperoleh dari partisipan, pada periode kepengurusan tersebut tidak terdapat suatu pengalaman yang memberikan pengaruh signifikan terhadap proses pembelajaran toleransi di ROHIS.

Penelitian ini berusaha untuk memberikan gambaran toleransi yang dimiliki oleh kelompok Remaja Islam. Hanya saja masih terdapat beberapa keterbatasan, di antaranya adalah perlunya unsur partisipan yang menjabat sebagai anggota divisi dan berasal dari berbagai angkatan. Partisipan dalam penelitian ini hanya koordinator divisi dan ketua umum yang berasal dari satu angkatan beserta ketua forum alumni dan pembina. Hal tersebut dilakukan karena tujuan dari penelitian adalah untuk menggambarkan toleransi dari para siswa. Koordinator divisi keputrian dan ketua umum merupakan pemimpin dari organisasi ekstrakurikuler. Nurkolis (2002) menyatakan bahwa budaya organisasi sangat dipengaruhi oleh tindakan para pemimpinnya. Hal tersebut sejalan dengan pernyataan Mintzberg dalam Sarwono (2005) yang menjelaskan mengenai peran-peran yang dimiliki oleh pemimpin organisasi. Beberapa peran pemimpin di antaranya adalah mengarahkan dan memberi pedoman pada pengikut. Pemimpin juga harus dapat menjadi teladan bagi bawahannya, serta merefleksikan karakter kelompok kepada pihak eksternal melalui perilaku dan penampilannya.

Berdasarkan penelitian ini, perlu disampaikan bahwa pengetahuan mengenai pendidikan multikulturalisme khususnya toleransi di Indonesia dapat ditingkatkan. Salah satunya dengan cara melakukan penelitian dalam jangkauan yang lebih luas, baik secara kualitatif maupun kuantitatif. Penelitian dengan metode kuantitatif diperlukan untuk melengkapi dan mendapatkan gambaran secara umum mengenai kondisi toleransi remaja Indonesia.

at.tentume. 1, No. 1, Januari - Juni 2016 


\section{Kesimpulan}

Kesimpulan dari hasil penelitian ini adalah pengurus ekstrakurikuler ROHIS pada suatu SMA di daerah Bekasi memiliki kategori toleransi pasif. Kategori tersebut disimpulkan karena terpenuhinya beberapa indikator. Pertama, Pengurus ROHIS menerima dan menghormati perbedaan yang ditunjukkan dengan sikap yang baik kepada pemeluk agama lain. Kedua, Motivasi pengurus ROHIS untuk menerima perbedaan muncul dari dalam diri sendiri, yaitu untuk menghindari konflik antara kelompok yang berbeda kepercayaan. Ketiga, Motivasi eksternal yang menjadi alasan pengurus ROHIS bertoleransi adalah kondisi sekolah yang merupakan milik pemerintah. Hal itu menyebabkan setiap warganya memiliki hak yang sama dalam menjalankan kegiatan keagamaan. Selain itu, pengurus juga menyadari tinggi tingkat keberagaman yang ada di Indonesia. Keempat, Pengurus ROHIS memberikan kesempatan dan tidak menghalangi kelompok agama lain untuk melakukan kegiatan ibadah. Namun, pengurus ROHIS tidak melakukan tindakan nyata untuk mendukung pelaksanaan kegiatan agama lain.

Berdasarkan pembahasan dalam diskusi maka diketahui bahwa terdapat dua jenis toleransi. Pertama adalah toleransi berupa tindakan yang sebenarnya dilakukan karena ada kepentingan untuk menguntungkan diri sendiri. Kedua adalah toleransi yang merupakan bentuk kebajikan yang dilakukan untuk menjaga kedamaian dalam hidup bersama orang lain ataupun karena menghormati orang lain. Pengurus ROHIS memiliki keduanya, dengan demikian yang perlu dilakukan adalah memelihara, menginternalisasi dan menguatkan adanya toleransi yang dilakukan atas dasar kebajikan.

Penelitian ini juga memberikan informasi bahwa pembelajaran toleransi dapat melibatkan berbagai pihak atau komponen dari ekstrakurikuler ROHIS, seperti pembina, mentor, sesama pengurus, seperti pemimpin organisasinya. Pembelajaran toleransi di ROHIS terjadi melalui diskusi, adanya kepercayaan terhadap orang lain yang lebih berkuasa seperti pembina, keteladanan dari mentor dan para pemimpinnya, dan adanya proses saling mempengaruhi antara kelompok kepada anggotanya dan sebaliknya. 


\section{Daftar Pustaka}

Almagor, Raphael Cohen. 1994. The boundaries of liberty and tolerance: The struggle against kahanism in Israel. Gainesville: University Press of Florida.

Bahari (ed.). 2010. Toleransi beragama mahasiswa. Jakarta: KEMENAG RI.

Chidester, D., Dexter, P., \& James, W. 2003. Whatholdustogether-social cohesion in South Africa. Cape Town: Human Science Research Council.

Chin, Chien dan Shahizan. 2006. Intrapersonal \& interpersonal untuk remaja. PTS Profesional Publishing Sdn. Bhd: Kuala Lumpur.

Cholil, S., Abidin, Z., Rahayu, M., \& Asyhari, B. 2009. Laporan tahunan kehidupan beragama di Indonesia 2009. Yogyakarta: CRCS.

Flick, Uwe., Kardorff, E. V., Steinke. Ines. 2004. A companion to qualitative research. California: Sage Publication Ltd. Hanum, Farida. 2009. Pentingnya pendidikan multikultural dalam mewujudkan demokrasi di Indonesia. Diakses pada tanggal 18 Maret 2012 dari http://staff.uny.ac.id/sites/default/files/pengabdian/faridahanum-msi-dr/pentingnya-pendidikan-multikultural-dalam-mewujudkandemokrasi-di-indonesia.pdf

Hasani, I (ed.). 2009. Berpihak dan bertindak intoleran. Jakarta: Setara Institut.

Kusmarwati \& Widiyantoro, N. 2002. Dakwah sekolah era baru. Di akses dari http://xa.yimg.com/kq/groups/14381082/594172848/name/Dakwah

Lacewing, Michael. 2008. Philosophy for AS. New York: Routledge.

Pastorino, Ellen \& Portillo, Susan Doyle. 2010. What is psychology?? essentials. Belmonth: Wadsworth Cengage Learning.

Raco, J. R. 2010. Metode penelitian kualitatif: jenis, karakteristik, dan keunggulannya. Jakarta: Grasindo.

Santrock J. W. 2008. Educational psychology third edition. New York: Mc-Graw Hill. 2003. Adolescence: Perkembangan remaja. Jakarta: Erlangga.

Sarwono, Sarlito Wirawan. 2005. Psikologi sosial: Psikologi kelompok dan psikologi terapan. Jakarta: Balai Pustaka.

| Volume. 1, No. 1, Januari-Juni 2016 
Ujan, A. A., dkk., 2009. Multikulturalisme belajar hidup bersama dalam perbedaan. Jakarta: Indeks.

Wade, Carol \& Tavris, Carol. 2008. Psikologi jilid 1 edisi 9. Jakarta: Erlangga.

Winarta, Frans H. 2009. Suara rakyat hukum tertinggi. Jakarta: Kompas media nusantara.

Zenger, John H., Folkman, Joseph R., \& Edinger, Scott K. 2012. The inspiring leader: unlocking the secretsof how extraordinary leaders motivate. US: McGraw-Hill. 